\title{
Risk for acute kidney injury in primary health care
}

\author{
Risco para lesão renal aguda na atenção primária à saúde \\ Riesgo de lesión renal aguda en la atención primaria de salu
}

Maria Célia Laranjeira Rigonatto', Marcia Cristina da Silva Magro'

' Universidade de Brasília, Faculty of Ceilândia, Undergraduate Program in Nursing. Brasília, Distrito Federal, Brazil.

How to cite this article:

Rigonatto MCL, Magro MCS. Risk for acute kidney injury in primary health care.

Rev Bras Enferm [Internet]. 2018;71(1):20-5. DOI: http://dx.doi.org/10.1590/0034-7167-2016-0551

Submission: 11-10-2016 Approval: 03-13-2017

\section{ABSTRACT}

Objective: To identify hypertensive and diabetic patients at risk for developing acute kidney injury in the primary health care setting. Method: Observational, longitudinal, prospective study. Sample of 56 diabetic and hypertensive individuals. A semistructured questionnaire was adopted for data collection. For the description of results, were calculated dispersion measures and the Spearman test was used for statistical analysis. The result was considered significant when $p<0.05$. Results: Of the total sample, $23.2 \%$ of users evolved with renal impairment, of which $19.6 \%$ with risk for renal injury, and $3.6 \%$ with kidney injury itself. Age and body mass index were associated with worsening of renal function $(p=0.0001 ; p=0.0003)$, respectively. Conclusion: A quarter of the health system users, hypertensive and diabetic, evolved with impaired renal function, more specifically to stages of risk for renal injury and kidney injury according to the RIFLE classification.

Descriptors: Acute Kidney Injury; Primary Health Care; Disease Prevention; Nursing evaluation; Hypertension.

\section{RESUMO}

Objetivo: Identificar pacientes hipertensos e diabéticos com risco para desenvolver lesão renal aguda no cenário da atenção primária à saúde. Método: Estudo observacional, longitudinal, prospectivo. Casuística composta de 56 indivíduos diabéticos e hipertensos. Adotou-se questionário semiestruturado para coleta de dados. Para descrição dos resultados foram calculadas medidas de dispersão e o teste de Spearman para análise estatística. O resultado foi considerado significativo quando $p<0,05$. Resultados: Do total, $23,2 \%$ dos usuários evoluíram com comprometimento renal, sendo 19,6\% com risco para lesão renal e 3,6\% com lesão renal, propriamente dita. A idade e $\mathrm{o}$ índice de massa corporal mostraram associação com a piora da função renal $(p=0,0001 ; p=0,0003)$, respectivamente. Conclusão: Identificou-se que um quarto dos usuários do sistema de saúde, hipertensos e diabéticos evoluíram com comprometimento da função renal, mais especificamente nos estágios de risco e de lesão renal segundo a classificação RIFLE. Descritores: Lesão Renal Aguda; Atenção Primária à Saúde; Prevenção de Doenças; Avaliação em Enfermagem; Hipertensão.

\section{RESUMEN}

Objetivo: Identificar los pacientes hipertensos y diabéticos con riesgo para desarrollar lesión renal aguda en el escenario de la atención primaria de salud. Método: Estudio observacional, longitudinal y prospectivo. Casuística compuesta de 56 individuos diabéticos e hipertensos. Un cuestionario semiestructurado fue adoptado para la recolección de datos. Para la descripción de los resultados, se calcularon medidas de dispersión, y para el análisis estadístico se usó la prueba de Spearman. El resultado se consideró significativo cuando $p<0,05$. Resultados: Del total de la muestra, el $23,2 \%$ de los usuarios evolucionaron con deterioro renal, siendo el 19,6\% con riesgo para lesión renal y el 3,6\% con lesión renal. La edad y el índice de masa corporal tuvieron asociación con el empeoramiento de la función renal $(p=0,0001 ; p=0,0003)$, respectivamente. Conclusión: Se identificó que un cuarto de los usuarios del sistema de salud, hipertensos y diabéticos, evolucionaron con alteración de la función renal, más específicamente en las etapas de riesgo y de lesión renal según la clasificación RIFLE.

Descriptores: Lesión Renal Aguda; Atención Primaria de Salud; Prevención de Enfermedades; Evaluación en Enfermería; Hipertensión. 


\section{INTRODUCTION}

Acute kidney injury (AKI) as a clinical syndrome is an issue to be considered for promoting patient safety ${ }^{(1-2)}$. It affects millions of people per year globally, despite being preventable when there is timely intervention ${ }^{(3)}$.

The Kidney Disease Improving Global Outcomes (KDIGO) criterion adopts changes occurring in serum creatinine within seven days to identify and stage $\mathrm{AKI}^{(2)}$. This syndrome is characterized by abrupt decline in renal function, signaled by increased serum creatinine and reduced urine output, which usually occurs within 48 hours after one or more clinical, surgical, and infectious events in both hospital and community settings ${ }^{(4)}$.

Diabetes mellitus and systemic arterial hypertension often coexist, and may modify the outcome of kidney disease. It is noteworthy that both conditions result in high risks for $\mathrm{AKI}$ in different settings ${ }^{(5-6)}$.

The prevalence of diabetes mellitus is estimated at around $4 \%$ to $34 \%$ of the general population, while in hypertension this percentage rises to $20 \%$ to $82 \%$. The establishment of measures to identify individuals at risk for AKI is essential for intervening early, i.e., before its evolution ${ }^{(7)}$.

The predisposition and risks for renal dysfunction should be identified and minimized. Individuals with diabetes mellitus and hypertension for six months accumulate risk for developing $\mathrm{AKI}$, as during this period there are losses in the renal blood flow self-regulation mechanism, which can lead to reduced renal perfusion ${ }^{(8)}$. In such cases, it is essential to maintain normal fluid balance, as well as balanced daily weight and hemodynamic measures where appropriate therefore, it should not be underestimated. Even the drug in use should be evaluated for potential nephrotoxicity. When necessary, doses should be adjusted to avoid renal impairment ${ }^{(9)}$.

Currently, community-acquired AKI is on the rise and represents a major public health problem. It has been associated with increase of mortality and hospital costs for the health system, which strengthens the need for early detection and implementation of guidance/education measures to mitigate its prevalence and potential complications ${ }^{(10-11)}$.

Certainly, prevention of AKI is the way to reduce demands for urgent care. Certain populations, such as individuals with diabetes and heart disease, are particularly at risk of developing complications associated with $\mathrm{AKI}^{(2-3,12)}$. The National Institute of Health and Care Excellence (NICE) recommends reporting the presence of a AKI risk to avoid this pathology when there are individuals in need of both maintaining fluid balance and temporarily ceasing certain drugs (including the angiotensin converting enzyme inhibitors - ACEI, non-steroidal anti-inflammatory drugs - NSAIDs, angiotensin II receptor blocker - ARB, and aminoglycosides) in acute episodes of the disease ${ }^{(11-12)}$.

At present, it is essential to develop health care aimed at prevention in order to mitigate the risks of disease chronification, the worsening of chronic diseases, the onset of new cases and comorbidities. Studies report the frequent onset of AKI primarily in the community by considering that many hospitalized patients present elevated serum creatinine since the time of admission, foretelling a previous history of the disease ${ }^{(13-15)}$. The care of individuals with AKI should be a priority regardless of where they are located for promoting their safety ${ }^{(2,16)}$.

Thus, the objective of this study was to identify hypertensive and diabetic patients at risk for developing acute kidney injury in the primary health care setting.

\section{METHOD}

\section{Ethical aspects}

This project was submitted and approved by the Research Ethics Committee of the Fundação de Ensino e Pesquisa em Ciências da Saúde of the SES - FEPECS/SES, and all participants signed the Informed Consent form (IC).

\section{Design, place and period of the study}

Observational, longitudinal, prospective study developed at a basic health unit (Portuguese acronym: UBS) of the Federal District, Brazil. Data collection comprised the period from July to August 2015.

\section{Population or sample; inclusion and exclusion criteria}

Fifty-six users of the Unified Health System (Brazilian SUS) aged 18 years or over, enrolled in the diabetes mellitus and hypertension care program, with no history of prior kidney injury were included in the study, according to the stage of RIFLE classification. Patients with a history of previous renal transplantation and history of chronic renal failure (glomerular filtration rate $<60 \mathrm{~mL} / \mathrm{min} / 1,73 \mathrm{~m}^{2}$ ) were excluded.

For sample size calculation (of users), was used the ratio estimation formula with the IBM Software Statistical Package for the Social Sciences (SPSS) Sample Power version 3.0. Given the large variation of AKI incidence published in scientific articles, was assumed the value of $50 \%$. A margin of error of $13 \%$ and $30 \%$ was adopted for possible losses. The alpha value adopted was $95 \%$. The sample size calculation resulted in 82 users.

Initially, the sample consisted of 84 users, but some factors described in the flowchart determined a final sample of 56 users (Figure 1).

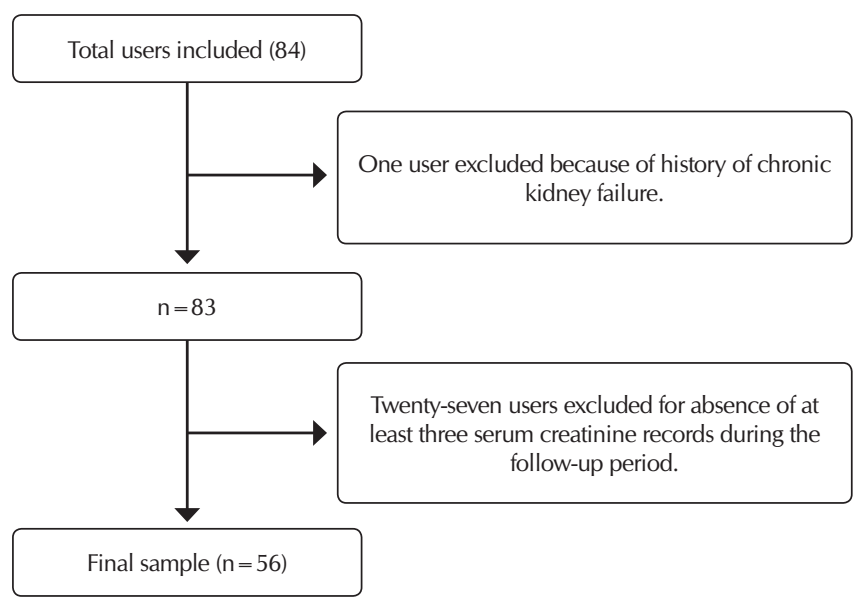

Figure 1 - Distribution of users forming the sample 


\section{Study protocol}

The operationalization of data collection occurred in steps, as follows.

In step 1, hypertensive and diabetic patients underwent a nursing consultation to investigate the family history, renal functioning and for anthropometric and hemodynamics (blood pressure) measurements. Detailed records of identification, clinical data and laboratory records were investigated in the electronic medical record.

Renal dysfunction in primary health care $(\mathrm{PHC})$ was identified both from changes in the value of serum creatinine measured routinely, according to the protocol of the Health Department, and from complaints of reduction or increase in urinary output, pain or discomfort for urination.

In step 2, users' renal impairment was classified using the RIFLE system. In this classification, are adopted two criteria for the evaluation of renal function, namely, serum creatinine and/or urinary output. In this study, was used only the serum creatinine criterion, given the limitation involved with strict control of urinary output in the primary care setting. Therefore, when serum creatinine increased by at least 1.5 times the baseline value, the patient was stratified as risk for kidney injury; if the increase was 2 times the baseline value, the patient was stratified as kidney injury; and when increase was 3 times the baseline value, patient was stratified as renal failure ${ }^{(2)}$.

\section{Analysis of results and statistics}

Records were stored in the Epi-info program, version 7 then, transferred to the SPSS, version 21 for statistical analysis. Values of relative and absolute frequency, mean and standard deviation, and the median $\left(25^{\text {th }}\right.$ and $75^{\text {th }}$ percentile) were calculated to describe the results.

For the analysis between continuous variables, was used the non-parametric Spearman test. Values of $p<0.05$ were considered significant.

\section{RESULTS}

\section{General aspects related to diabetic and hyperten- sive patients}

The average age of users was $63 \pm 9.7$ years. Obesity was a characteristic of the group (BMI $31 \pm 5 \mathrm{~kg} /$ $\left.\mathrm{m}^{2}\right)$. Female sex and white race predominated $(67.9 \%$, $41.1 \%$ ), respectively (Table 1 ).

When analyzing the family history, over half of users $(57.1 \%)$ reported having a family member with both diabetes mellitus and hypertension (58.9\%). In both cases, the most cited family member was the mother, in $35.7 \%$ and $46.4 \%$ of cases, respectively (Table 2 ).

Of the total number of subjects, $94.6 \%$ and $92.9 \%$ reported knowing that uncontrolled diabetes mellitus and hypertension can compromise renal function, respectively (Table 2 ).
Table 1 - Distribution of health unit users according to clinical characteristics, Distrito Federal, Brazil, 2016

\begin{tabular}{|c|c|c|}
\hline Characteristics $(n=56)$ & Mean \pm SD & n (\%) \\
\hline Male sex & - & $18(32.1 \%)$ \\
\hline Age (years) & $63.9 \pm 9.7$ & - \\
\hline $\mathrm{BMI} *\left(\mathrm{~kg} / \mathrm{m}^{2}\right)$ & $31 \pm 5$ & - \\
\hline Obese $\left(\mathrm{BMI} \geq 30 \mathrm{~kg} / \mathrm{m}^{2}\right)$ & - & $25(44.6 \%)$ \\
\hline Overweight (BMI $\geq 25 \mathrm{~kg} / \mathrm{m}^{2}$ and $\mathrm{BMI} \geq 30 \mathrm{~kg} / \mathrm{m}^{2}$ ) & - & $23(41.1 \%)$ \\
\hline Renal dysfunction & - & $13(23.2 \%)$ \\
\hline Lower creatinine clearance & $74 \pm 27$ & - \\
\hline \multicolumn{3}{|l|}{ Ethnicity } \\
\hline White & - & $23(41.1 \%)$ \\
\hline Mixed race & - & $9(16.1 \%)$ \\
\hline Black & - & $22(39.3 \%)$ \\
\hline Smoker & - & $2(3.6 \%)$ \\
\hline Alcoholic & - & $6(10.7 \%)$ \\
\hline \multicolumn{3}{|l|}{ Residence } \\
\hline Ceilândia Norte & - & $55(98.2 \%)$ \\
\hline Ceilândia Sul & - & $1(1.8 \%)$ \\
\hline \multicolumn{3}{|l|}{ Religion } \\
\hline No religion & - & $3(5.4 \%)$ \\
\hline Catholic & - & $30(53.6 \%)$ \\
\hline Evangelical & - & $23(41.1 \%)$ \\
\hline Lives alone & - & $6(10.7 \%)$ \\
\hline
\end{tabular}

Note: $B M I=$ body mass index; $S D=$ standard deviation

Table 2 - Family history and users' knowledge about systemic arterial hypertension $(\mathrm{SAH})$ and diabetes mellitus (DM), Distrito Federal, Brazil, 2016

\begin{tabular}{|c|c|}
\hline Characteristics $(n=56)$ & n (\%) \\
\hline \multicolumn{2}{|l|}{ Family history of DM } \\
\hline Does not know & $5(8.9 \%)$ \\
\hline No & $19(33.9 \%)$ \\
\hline Yes & $32(57.1 \%)$ \\
\hline \multicolumn{2}{|l|}{ Family member with DM } \\
\hline Father & $9(16.1 \%)$ \\
\hline Mother & $20(35.7 \%)$ \\
\hline Father and mother & $5(8.9 \%)$ \\
\hline Grandfather or grandmother & $1(1.8 \%)$ \\
\hline Uncle or aunt & $15(26.8 \%)$ \\
\hline \multicolumn{2}{|l|}{ Family history of SAH } \\
\hline Does not know & $7(12.5 \%)$ \\
\hline No & $16(28.6 \%)$ \\
\hline Yes & $33(58.9 \%)$ \\
\hline \multicolumn{2}{|l|}{ Family member with $\mathrm{SAH}$} \\
\hline Father & $11(19.6 \%)$ \\
\hline Mother & $26(46.4 \%)$ \\
\hline Father and mother & $7(12.5 \%)$ \\
\hline Grandfather or grandmother & $1(1.8 \%)$ \\
\hline Uncle or aunt & $12(21.4 \%)$ \\
\hline \multicolumn{2}{|c|}{ Knowledge that uncontrolled DM impairs the kidney } \\
\hline No & $3(28.6 \%)$ \\
\hline Yes & $53(94.6 \%)$ \\
\hline \multicolumn{2}{|c|}{ Knowledge that uncontrolled SAH impairs the kidney } \\
\hline No & $4(7.1 \%)$ \\
\hline Yes & $52(92.9 \%)$ \\
\hline Practice of physical activity & $21(37.5 \%)$ \\
\hline
\end{tabular}


Table 2 (concluded)

\begin{tabular}{cc}
\hline Characteristics $(\mathbf{n}=\mathbf{5 6})$ & $\mathbf{n}(\mathbf{\%})$ \\
\hline Blood pressure level at time of consultation & \\
Optimal $(\mathrm{SP}<120 \mathrm{mmHg} ; \mathrm{DP}<80 \mathrm{mmHg})$ & $8(14.3 \%)$ \\
Normotensive $(\mathrm{SP}<130 \mathrm{mmHg}$; $\mathrm{DP}<85 \mathrm{mmHg})$ & $19(33.9 \%)$ \\
Borderline $(\mathrm{SP}=130-139 \mathrm{mmHg} ; \mathrm{DP}=85-89 \mathrm{mmHg})$ & $10(17.9 \%)$ \\
Hypertensive $(\mathrm{SP} \geq 140-159 \mathrm{mmHg} ; \mathrm{DP} \geq 90-99 \mathrm{mmHg})$ & $18(32.1 \%)$ \\
\hline
\end{tabular}

Note: $S P=$ systolic pressure; $D P=$ diastolic pressure; $S A H=$ systemic arterial hypertension; $D M=$ diabetes mellituss

A little less than half of hypertensive users (48.2\%) had blood pressure under control (within normal limits). Of these, at the time of the consultation, in $14.3 \%$ the blood pressure was classified as optimal, and $33.9 \%$ were considered normotensive (Table 2).

There were 13 cases in the sample, that is, $23.2 \%$ of individuals with renal dysfunction. The mean value of the lowest creatinine clearance was $74 \pm 27 \mathrm{~mL} / \mathrm{min} / 1.73 \mathrm{~m}^{2}$ (Table 1 ).

The creatinine criterion of the RIFLE classification was used to evaluate users' renal function. Assuming RIFLE as a diagnostic and classificatory criterion, the majority of the sample $(76.8 \%)$ did not present impaired renal function. On the other hand, $19.6 \%$ were at risk of developing kidney injury, and $3.6 \%$ were in stage of kidney injury itself.
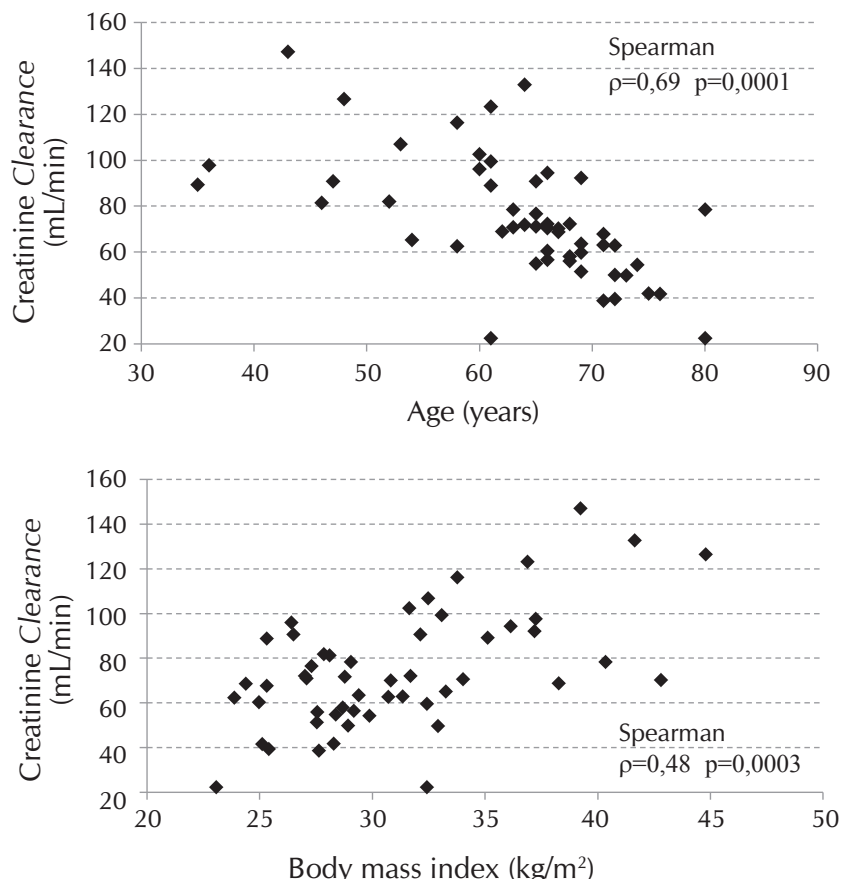

Figure 2 - Relationship between creatinine clearance and age (years) and body mass index $\left(\mathrm{kg} / \mathrm{m}^{2}\right)$ of the health unit users, Distrito Federal, Brazil, 2016

Worsening of creatinine clearance was found in both patients aged $60-75$ years $(p=0.0001)$ and in those with BMI between 25 and $35 \mathrm{~kg} / \mathrm{m}^{2}(\mathrm{p}=0.0003)$ (Figure 2).

\section{DISCUSSION}

The Brazilian health situation has been changing considerably over the years. It is currently aligned with the accelerated demographic transition expressed by a triple burden of diseases that is determined by a number of external causes and, above all, by the hegemonic presence of chronic conditions such as arterial hypertension and diabetes mellitus ${ }^{(6)}$.

The literature has strong evidence demonstrating patients with diabetes mellitus and hypertension undergo functional and structural changes in target organs such as the heart, brain, kidneys and blood vessels. From this perspective, the present study can also demonstrate that having such comorbidities raises the risk of developing $\mathrm{AKI}^{(13,17)}$.

As observed in this study, the development of kidney injury in the elderly has increased in present times. Certainly, the elderly are more likely to develop AKI, for example, because they accumulate arteriosclerosis, arterial hypertension, diabetes mellitus and heart failure, in addition to the common polypharmacy for the treatment of comorbidities that has increased prevalence with age ${ }^{(18)}$.

Scientific evidence has shown the development of AKI in the primary care setting by nearly two-thirds of patients ${ }^{(19)}$. There was a similar finding in our study, considering that a quarter of participants developed this pathology.

Despite the lack of consensus between the association of obesity and the occurrence of health complications, obese individuals are generally predisposed to greater risk of complications compared to those in the normal weight range. Given the high prevalence of diabetes, hyperglycemia and obesity in individuals under health treatment, there is an association of these conditions with $\mathrm{AKI}$, as also indicated in this study. The AKI can aggravate individuals' outcomes and often indicate the need for continued attention to minimize complications and avoid progression to a chronic condition ${ }^{(20)}$.

Individuals with body mass index values $\geq 25 \mathrm{~kg} / \mathrm{m}^{2}$ are known to be more predisposed to the risk of death and increased prevalence of AKI. The probability of developing AKI in obese individuals is twice as high when compared to individuals within the normal range of body mass index ${ }^{(21)}$.

A precise family health history is essential for individual risk assessment. Studies such as this have shown the positive family history and low educational level are predictors of chronic diseases such as hypertension and diabetes ${ }^{(22-23)}$.

$\mathrm{AKI}$, even if considered as mild or moderate stage, may result in increased morbidity and mortality ${ }^{(24)}$, especially when there is predominance of elderly individuals, as identified in this study.

Such a scenario is concerning, since studies have identified reduced recovery of renal function in the elderly after AKI. Physiologically, the elderly are more susceptible to AKI, and it is important to understand the association of this pathology with a more or less severe consequence for this population ${ }^{(25)}$.

The strict control of hypertension and diabetes is a strategy that should reduce the risk of renal complications ${ }^{(26)}$. In addition, a study showed hypertension and diabetes are risk factors for $\mathrm{AKI}^{(27)}$. For these reasons, the monitoring and reduction of factors contributing to $\mathrm{AKI}$ in vulnerable patients is essential, such as those with chronic diseases as hypertension and diabetes ${ }^{(28)}$.

The implementation of measures to disseminate, diversify and democratize health services can be the solution 
for service improvement and achieving the desired goals in health promotion and prevention ${ }^{(29)}$.

\section{Limitations of the study}

The limitations of this study were related to the lack of data in electronic medical records and the fact that it is a single center study.

\section{Contributions to the area of nursing, health or public policy}

The contribution was based on indicators for early recognition of renal dysfunction in the PHC setting, and on showing the importance of health professionals' participation, especially nurses, in the identification of common and frequent renal diseases in diabetic and hypertensive patients. This can certainly contribute to the creation of management strategies aimed at a better targeting of care and reduction of AKI evolution for a chronic condition and less burden on the health system.

\section{CONCLUSION}

In this study, a quarter of the health system users, hypertensive and diabetic, evolved with impaired renal function, more specifically in the stages of risk of kidney injury and kidney injury according to the RIFLE classification.

\section{REFERENCES}

1. Lewington A, Hall P. The cost of ignoring acute kidney injury. Nephrol Dial Transplant [Internet]. 2014 [cited 2015 Aug 01];29(7):1270-2. Available from: http://ndt.oxfordjournals.org/content/early/2014/04/10/ndt.gfu060.full

2. Kidney Disease: Improving Global Outcomes (KDIGO) Acute Kidney Injury working group. KDIGO Clinical Practice Guideline for Acute Kidney Injury. Kidney Int Suppl [Internet]. 2012 [cited 2015 Aug 01];2:1-138. Available from: http://www.kdigo.org/ clinical_practice_guidelines/pdf/KDIGO \%20AKI\%20Guideline.pdf

3. Metha RL, Cerda J, Burdmann EA, Tonelli M, Garcia-Garcia G, Susantitaphong P, et al. International Society of Nephrology's Oby25 initiative for acute kidney injury (zero preventable deaths by 2025): a human rights case for nephrology. Lancet [Internet]. 2015 [cited 2015 Aug 01];385(9987):2616-43. Available from: http://www.thelancet.com/pdfs/journals/lancet/PIIS01406736(15)60126-X.pdf

4. Vrtis MC. Preventing and responding to acute kidney injury: how to recognize the incremental changes in kidney function that adversely affect patient outcomes. Am J Nurs [Internet]. 2013 [cited 2015 Aug 01];113(4):38-47. Available from: https://www.ncbi. nlm.nih.gov/pubmed/23492807

5. Mahmoodi BK, Matsushita K, Woodward M, Blankestijn PJ, Cirillo M, Ohkubo T, et al. Associations of kidney disease measures with mortality and end-stage renal disease in individuals with and without hypertension: a meta-analysis. Lancet [Internet]. 2012 [cited 2015 Aug 01];380(9854):1649-61. Available from: https://www.ncbi.nlm.nih.gov/pmc/articles/PMC3993095/

6. Fox CS, Matsushita K, Woodward M, Bilo HJ, Chalmers J, Heerspink HJ, et al. Associations of kidney disease measures with mortality and end-stage renal disease in individuals with and without diabetes: a meta-analysis. Lancet [Internet]. 2012 [cited 2015 Aug 01];380(9854):1662-73. Available from: https://www.ncbi.nlm.nih.gov/pmc/articles/PMC3771350/

7. James MT, Grams ME, Woodward M, Elley CR, Green JA, Wheeler DC, et al. A meta-analysis of the association of estimated GFR, albuminuria, diabetes mellitus, and hypertension with AKI. Am J Kidney Dis [Internet]. 2015 [cited 2015 Aug 01];66(4):602-12. Available from: https://www.ncbi.nlm.nih.gov/pmc/articles/PMC4594211/

8. Singh P, Rifkin DE, Blantz RC. Chronic kidney disease: an inherent risk factor for acute kidney injury? Clin J Am Soc Nephrol [Internet]. 2010 [cited 2017 Feb];5:1690-95. Available from: http://cjasn.asnjournals.org/content/5/9/1690.full.pdf + html

9. Kellum JA, Leblanc M, Gibney RT, Tumlin J, Lieberthal W, Ronco C. Primary prevention of acute renal failure in the critically ill. Curr Opin Crit Care [Internet]. 2005 [cited 2015 Aug 01];11(6):537-41. Available from: https://www.ncbi.nlm.nih.gov/ pubmed/16292056

10. Kerr M, Bedford M, Matthews B, O'Donoghue D. The economic impact of acute kidney injury in England. Nephrol Dial Transplant [Internet]. 2014 [cited 2015 Aug 01];29(7):1362-8. Available from: http://ndt.oxfordjournals.org/content/29/7/1362.full.pdf + html

11. De La Fuente V, Stucker F, Saudan P. Epidemiology of community-acquired acute kidney injury. Rev Med Suisse [Internet]. 2014 [cited 2015 Aug] 26;10(419):470-3. Available from: https://www.ncbi.nlm.nih.gov/pubmed/24665655

12. National Institute for Health and Care Excellence (NICE). Acute Kidney Injury: prevention, detection and management. Clinical Guideline[Internet]. 28 August 2013[cited 2015 Jul 08]. Available from: nice.org.uk/guidance/cg169

13. Selby NM, Crowley L, Fluck RJ, Mclntyre CW, Monaghan J, Lawson N, et al. Use of electronic results reporting to diagnose and monitor AKI in hospitalized patients. Clin J Am Soc Nephrol [Internet]. 2012 [cited 2015 Aug 01];7(4):533-40. Available from: http://cjasn.asnjournals.org/content/7/4/533.full.pdf + html

14. Wonnacott A, Meran S, Amphlett B, Talabani B, Phillips A. Epidemiology and outcomes in community-acquired versus hospitalacquired AKI. Clin J Am Soc Nephrol [Internet]. 2014 [cited 2015 Aug 01];9:1007-14. Available from: https://www.ncbi.nlm.nih. gov/pmc/articles/PMC4046725/

15. Schissler MM, Zaidi S, Kumar H, Deo D, Brier ME, McLeish KRL. Characteristics and outcomes in community-acquired versus 
hospital-acquired acute kidney injury. Nephrology [Internet]. 2013 [cited 2015 Aug 01];18:183-7. Available from: http:// onlinelibrary.wiley.com/doi/10.1111/nep.12036/pdf

16. Morrison C, Wilson M. Medicine sick day rules cards-Interim evaluation. 2014. Available from: http://margaretmccartney.com/ wp-content/uploads/2014/10/NHSH-interim-evaluation-medicine-sick-day-rules.pdf

17. Abascal REC, Febles OF, Simón OG, Padrón RG, Moya OA. Nefropatía diabética en pacientes diabéticos tipo 2. Rev Cubana Med[Internet]. 2011[cited 2015 Aug 01];50(1):29-39. Available from: http://scielo.sld.cu/pdf/med/v50n1/med03110.pdf

18. Park JY, An JN, Jhee JH, Kim DK, Oh HJ, Kim S, et al. Early initiation of continuous renal replacement therapy improves survival of elderly patients with acute kidney injury: a multicenter prospective cohort study. Crit Care [Internet]. 2016 [cited 2015 Aug 01];16;20(1):260. Available from: https://www.ncbi.nlm.nih.gov/pmc/articles/PMC4986348/

19. Selby NM, Crowley L, Fluck RJ, Mclntyre CW, Monaghan J, Lawson N, et al. Use of electronic results reporting to diagnose and monitor AKI in hospitalized patients. Clin J Am Soc Nephrol [Internet]. 2012 [cited 2015 Aug 01];7(4):533-40. Available from: http://cjasn.asnjournals.org/content/7/4/533.full.pdf + html

20. Alexopoulos AS, Fayfman M, Zhao L, Weaver J, Buehler L, Smiley D, et al. Impact of obesity on hospital complications and mortality in hospitalized patients with hyperglycemia and diabetes. BMJ Open Diabetes Res Care [Internet]. 2016 [cited 2016 Aug 01];8;4(1):e00020. Available from: https://www.ncbi.nlm.nih.gov/pmc/articles/PMC4947725/

21. Hutagalung R, Marques J, Kobylka K, Zeidan M, Kabisch B, Brunkhorst F, et al. The obesity paradox in surgical intensive care unit patients. Intensive Care Med [Internet]. 2011 [cited 2015 Aug 01];37:1793-9. Available from: http://www.jccjournal.org/article/ S0883-9441(14)00227-5/pdf

22. Abdelsatir S, Al-Sofi A, Elamin S, Abu-Aisha $\mathrm{H}$. The potential role of nursing students in the implementation of community-based hypertension screening programs in Sudan. Arab J Nephrol Transplant [Internet]. 2013 [cited 2015 Feb 01];6:51-4. Available from: http://www.ajol.info/index.php/ajnt/article/view/84345/74346

23. Tee SR, Teoh XY, Aiman WA, Aiful A, Har CS, Tan ZF, et al. The prevalence of hypertension and its associated risk factors in two rural communities in Penang, Malaysia. Inter E-J Sci Med Educ[Internet]. 2010 [cited 2015 Feb 01];4:27-40. Available from: http:// web.imu.edu.my/ejournal/approved/5.Original_TanSyerRee.pdf

24. Turgutalp K, Bardak S, Horoz M, Helvacı I, Demir S, Kiykim AA. Clinical outcomes of acute kidney injury developing outside the hospital in elderly. Int Urol Nephrol [Internet]. 2017 [cited 2015 Feb 01];49(1):113-121. Available from: https://www.ncbi.nlm. nih.gov/pubmed/27704319

25. Schissler MM, Zaidi S, Kumar H, Deo D, Brier ME, McLeish KR. Characteristics and outcomes in community-acquired versus hospital-acquired acute kidney injury. Nephrol[Internet]. 2013 [cited 2015 Feb 01];18(3):183-7. Available from: https://www. ncbi.nlm.nih.gov/pubmed/23336108

26. Araki SI, Haneda M, Koya D, Kondo K, Tanaka S, Arima H, et al. Urinary potassium excretion and renal and cardiovascular complications in patients with type 2 diabetes and normal renal function. Clin J Am Soc Nephrol [Internet]. 2015 [cited 2015 Feb 01];10(12):2152-8. Available from: https://www.ncbi.nlm.nih.gov/pmc/articles/PMC4670758/

27. Khan FG, Ahmed E. Acute renal failure in diabetes mellitus. JPMA [Internet]. 2015 [cited 2015 Feb 01];65:179. Available from: https://www.ncbi.nlm.nih.gov/pubmed/25842555

28. Rewa O, Bagshaw SM. Acute kidney injury-epidemiology, outcomes and economics. Nat Rev Nephrol [Internet]. 2014 [cited 2015 Feb 01];10:193-20. Available from: https://www.ncbi.nlm.nih.gov/pubmed/24445744

29. Conselho Regional de Enfermagem. Protocolos de enfermagem na atenção primária a saúde. [Internet]. Rio de janeiro, 2012[cited 2016 Oct 15]. Available from: http://www.rio.rj.gov.br/dlstatic/10112/4446958/4111921/enfermagem.pdf 